Palestine Exploration Quarterly

\title{
Crosses on the Mosque of the Dome of the Rock, Jerusalem
}

\section{Robert Williams}

To cite this article: Robert Williams (1913) Crosses on the Mosque of the Dome of the Rock, Jerusalem, Palestine Exploration Quarterly, 45:4, 178-183, DOI: 10.1179/peq.1913.45.4.178

To link to this article: http://dx.doi.org/10.1179/peq.1913.45.4.178

曲 Published online: 19 Jul 2013.

Submit your article to this journal ¿

Џ Article views: 9

Q View related articles $\longleftarrow$ 


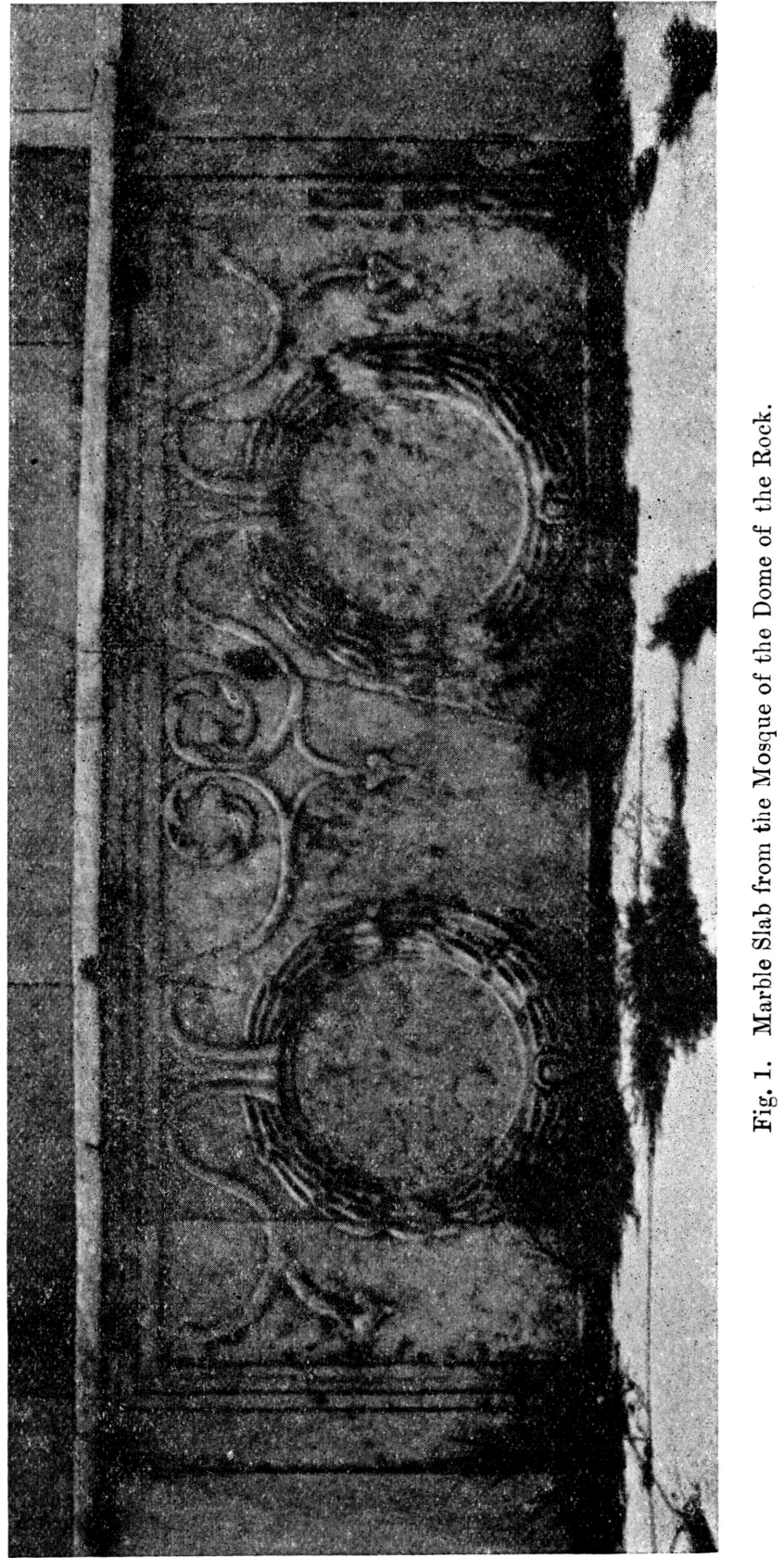




\section{CROSSES ON THE MOSQUE OF THE DOME OF THE ROCK, JERUSALEM.}

By Robert Williams, Alexandria.

THE accompanying photograph (Fig. 1), represents one of the marble slabs forming part of the outer casing of the base of the Mosque of the Dome of the Rock. The ornament carved on the slab is very similar to that on a fallen architrave (Fig. 2) of the Basilica built by Theodosius at Baalbek at the end of the fourth century A.D., and destroyed by the Arabs in the seventh century.

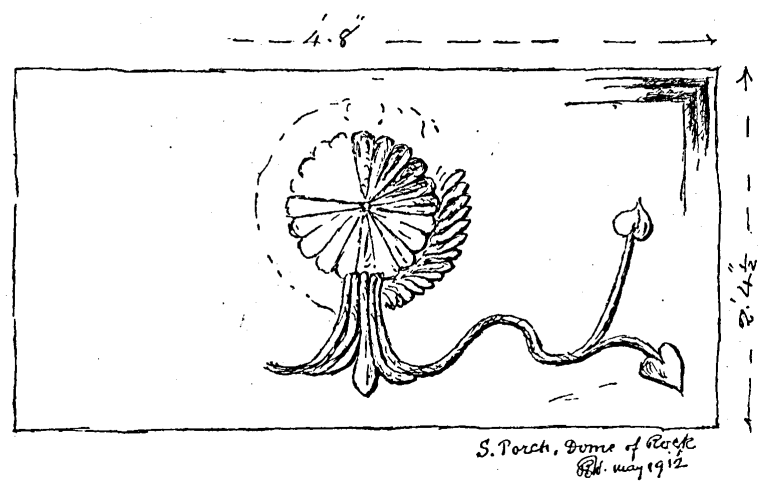

Fig. 3. From the Porch of the Mosque of the Dome of the Rock.

Within the carved wreaths, both at Baalbek and on the slab, are plain indications of crosses in relief having been chipped off.

The central wreath on the architrave is emphasized by the letters Alpha and Omega and large heart-shaped leaves and tendrils of the usual early Byzantine pattern. The Alpha is much larger than the Omega. Neither of the letters were chipped. All these wreaths and crosses bear a striking resemblance to those carved on a sarcophagus at Ravenna, and illustrated on p. 267 of Diehl's Manuel d'Art Byzantin. There are also drawings of similar crosses and wreaths in Sir T. Jackson's Byzantine and Romanesque Architecture, just published. The period generally assigned to these crosses is from 


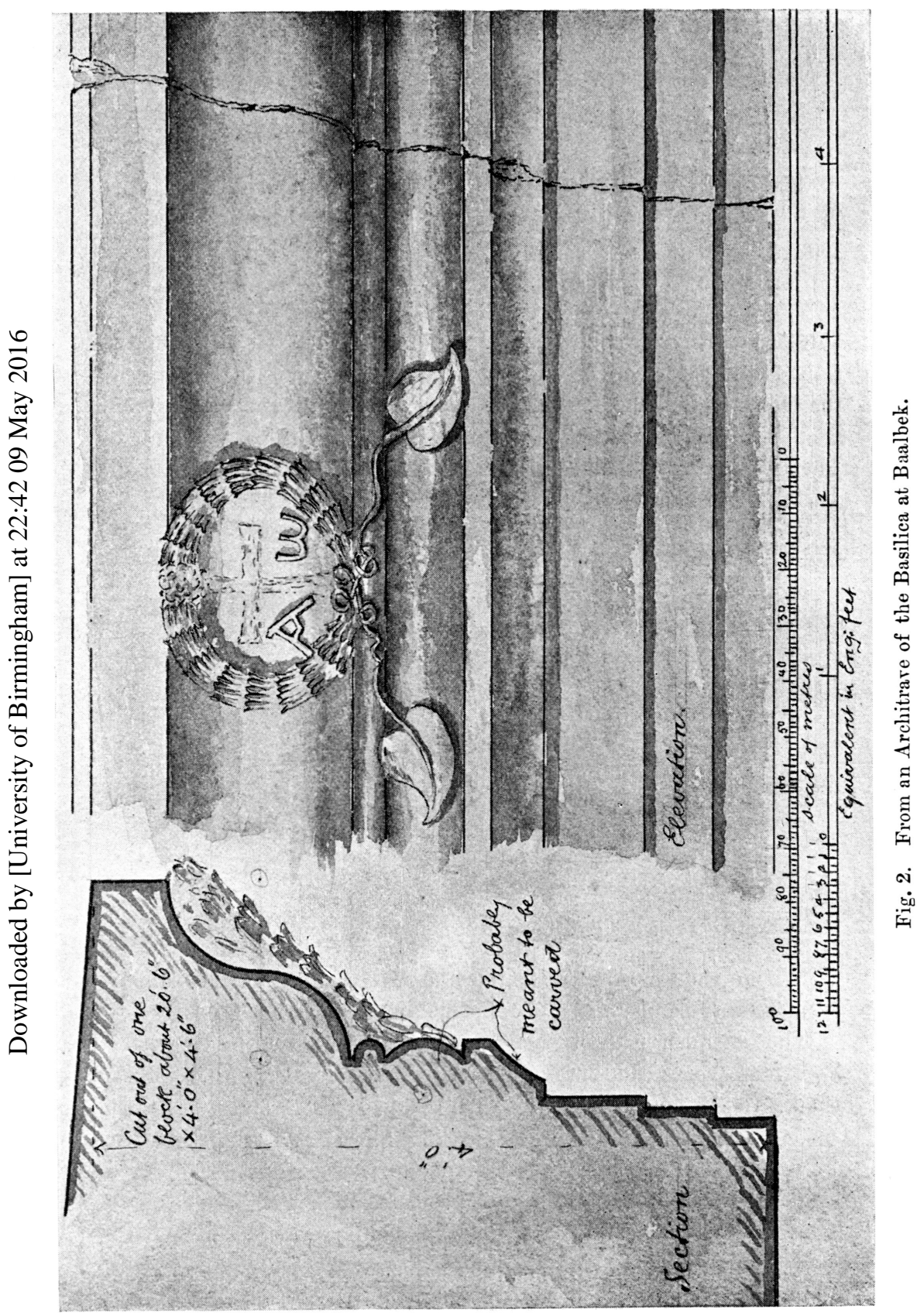


the fourth to the sixth centuries, and this compares with the dates A.D. 379-395 of the crosses at Baalbek.

There are, however, other similar slabs ornamenting the Dome of the Rock and the Mosque of Al-Aksa. Fig. 3 is a slab fixed on the outside of the North Porch. In this slab the wreath is slightly dissimilar, and contains, instead of a cross proper, a fluted, shell-like ornament. The leaves and tendrils are the same. In the Mosque of AlAksa are two slabs (Fig. 4), one on either side of the mihrab, having similar wreaths, but they have been painted over, and the centre of each filled with an eight-pointed star. In the chapel of Zachariah in this Mosque there is a

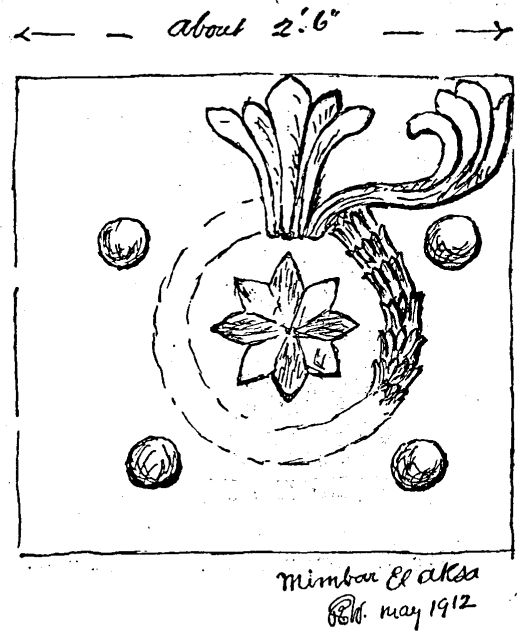

Fig. 4. From the Mosque of Al-Aksa. similar slab (Fig. 5), with wreath and chipped off cross. The slab is fixed over an old doorway.

The interesting question now arises: How came the Mohammedan builders of the Mosque of the Dome of the Rock to use

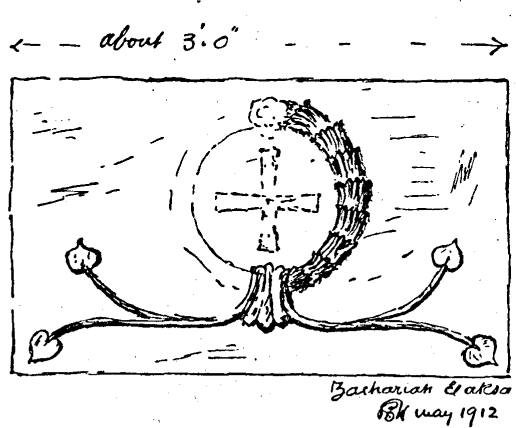

Fig. 5. From the Chapel of Zachariah. these slabs with their evident Christian symbols, none too carefully obliterated? And when were they placed in the position in which we now see them?

The Mosque of the Dome of the Rock was built; it is said, by Abd el-Malīk about A.D. 688. Were the "slabs, which had evidently been part of a Christian edifice, altered and used by the Mohammedan architects when they built the Mosque? It seems hardly credible: that the thin lining of marble could have remained secure for twelve centuries. 
It is possible, and even probable, that the slabs ornamented with the crosses and early Byzantine foliage were found or imported and built in by the Crusaders, and the double one (Fig. 1), was chosen to mark the eastern or Sanctuary side of the building when, in the eleventh century, they turned it into a church, which, a hundred

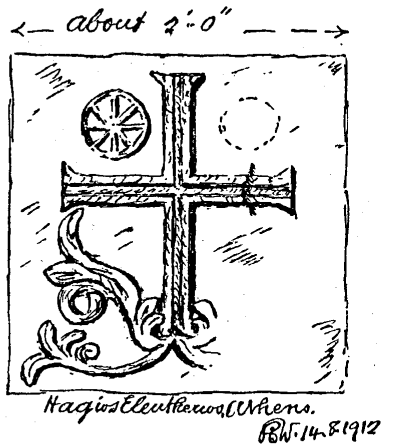

Fig. 6. From a Church at Athens.

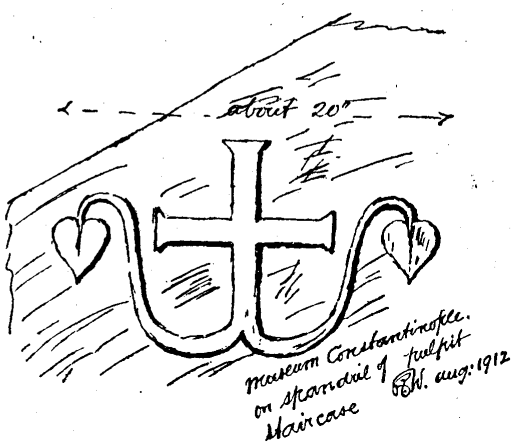

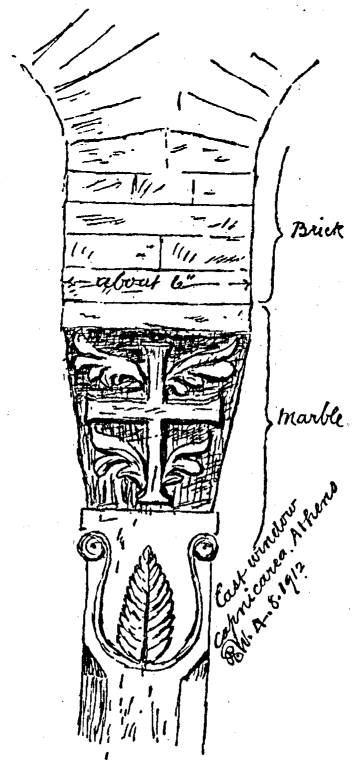

Fig. 7. From a Church at Athens.

Fig. 8. From the Constantinople Museum.

years later, reverted to the Mohammedans who had the crosses chipped off (see Conder's Latin Kingdom of Jerusalem, pp. 107, 157).

There is just another conjecture, namely, that the base of the Dome of the Rock was lined with marble at the time of the casing of the upper part with Persian tiles in the sixteenth century.

The slabs (Figs. 1 and 4) are, it should be noted, built upsidedown, while the slabs of the north porch and the chapel of Zachariah are correctly fixed. 
It is curious that there is no reference in Fergusson to these slabs; nor is there a reference to the Christian remains at Baalbek to be found in the folio published by Wood and Dawkins in the eighteenth century.

For the purpose of comparison a few other illustrations are given :-

Fig. 6 is a panel brought, most likely, from an older church and built into the wall of the "Little Metropolis" (Hagios Eleutherios) at Athens.

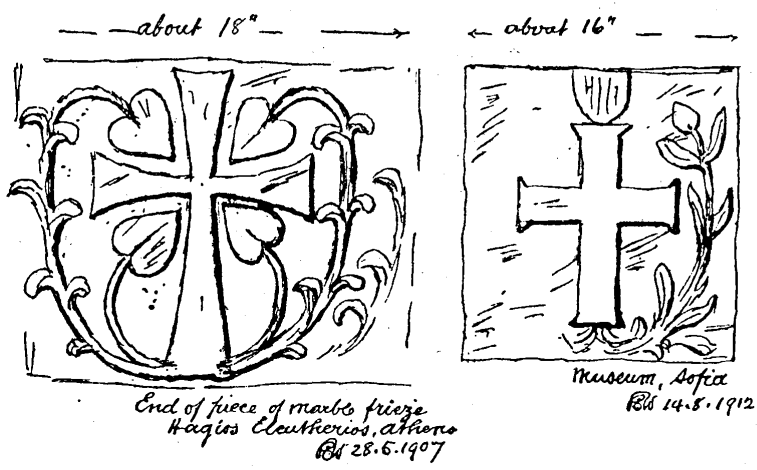

Figs. $9 a$ and $b$. Decorative Crosses.

Fig. 7 is from the interesting little church called Capnicarea, Athens, which, by a notice within it, we are told dates from A.D. 418.

Fig. 8 is from the side of the staircase to a pulpit now in the museum at Constantinople.

Fig. $9 a$ is from the same church as Fig. 6. The cross is at the end of an ancient pagan frieze built in promiscuously. This, too, is from some older building, and it was Christianized by adding the cross.

Fig. $9 b$ is from a little panel in the museum in Sofia, Bulgaria. 